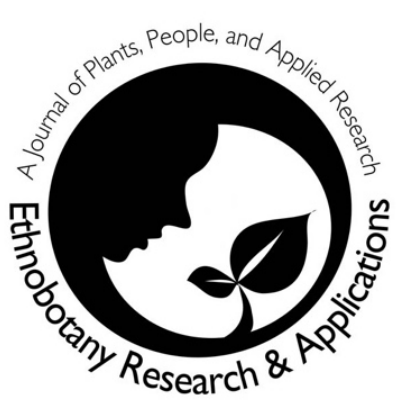

\title{
Ethnomedicinal use of plant resources in Kirtinagar Block of Tehri Garhwal in Western Himalaya
}

\author{
Atul Pratap Singh, Munesh Kumar, Bhuvnesh Nagar, \\ Nazir A. Pala, and Rainer W. Bussmann
}

\section{Databases and Inventories}

\begin{abstract}
Background: The aim of the present study is to report the cultural importance and utilization of ethnomedicinal plant species among the communities of Tehri district in Garhwal Himalaya, India.
\end{abstract}

Methods: The ethnomedicinal uses of plants were collected from participants of the villages based on randomly selected inhabitants through semi structured interviews. A total of 93 respondents provided information.

Results: The documentation recorded a total of 92 ethnobotanical plant species including trees (52), shrubs (19), herbs (18) and climbers (3). Out of 92 species, only 35 species were used for ethnomedicinal purposes to cure 30 different ailments prevailing in the area. The maximum number of species (9) was used for stomach disorders followed by diabetes and wounds (4 each), and fractures and tooth problems (3 each). The informant consensus factor $\left(F_{i c}\right)$ for joint pain was 0.0 whereas $F_{\text {ic }}$ value for other species ranged from 0.600 to 1.0 . The fidelity level (FL) was highest $(100 \%)$ for 14 species and the lowest value of $F L$ (20\%) was recorded for Eupatorium adenophorum. The Cultural Importance Index $(\mathrm{Cl})$ was highest for Barleria cristata (0.15) and lowest (0.01) for Azadirachta indica and Boehmeria rugulosa each.

Conclusion: The study revealed that the large number of ethnobotanical plant species exists in the area. Increased awareness on conservation and developmental strategies is needed to utilize resources through sustainable development.

Keywords: Villagers, dependency, ethnomedicinal plants, cures, diseases
सार

पृष्ठभमिः वर्तमान अध्ययन का उद्देष्य गढ़वाल हिमालय (भारत) में टिहरी गढ़वाल जिले के समुदायों के बीच पारम्परिक औषधीय पौधों के सांस्कृतिक महत्व और उपयोग का मूल्यांकन करना है।

विधिः पौधों की औषधीय उपयोग की जानकारी गॉव के निवासी प्रतिभागियों से अर्द्ध.संचरित साक्षात्कार के माध्यम से यादृच्छिक रूप से एकत्रित की गयी। कुल 93 उत्तरदाताओं द्वारा जानकारी प्रदान की गयी है।

\section{Correspondence \\ Atul Pratap Singh \\ Munesh Kumar* \\ Bhuvnesh Nagar \\ Nazir A. Pala \\ Rainer W. Bussmann}

Department of Forestry and Natural Resources, HNB Garhwal University (A Central University),

Srinagar Garhwal, Uttarakhand 249161,

India*Corresponding author:

muneshmzu@yahoo.com

\section{Ethnobotany Research \& Applications}

18:14 (2019)

परिणामः इस प्रलेखन में कुल 92 औषधीय पौधों की प्रजातियों को दर्ज किया गयाए में 52 पेड़ों, 19 झाड़ियों, 18 जड़ी बूटियों और 03 बेलों की प्रजातियों को दर्ज किया गया। 92 प्रजातियों में से केवल 35 प्रजातियॉ ही औषधीय उद्देष्यों के लिए उपयोग की जाती है। जो इस क्षेत्र में प्रचलित 30 विभिन्न बिमारियों का ईलाज करती हैं। उक्त प्रजातियों में से सर्वाधिक 09 प्रजातियों का अधिकतम संख्या में पेट के रोगों के लिए उपयोग किया जाता है। इसके बाद 04 प्रजातियों का उपयोग मधुमेह और जख्म के निदान हेतु उपयोग किया गया है। हड्डी टूटने एवं दॉतों की समस्या के समाधान के लिए 03 प्रजातियों का उपयोग किया गया। संयुक्त दर्द के लिए सर्वसम्मति के आधार पर सूचना देने वाला कारक (Informant Consensus Factor - FIC) का मान 0.0 था। जबकि अन्य औषधीय पौधों के लिए यह मान 0.600 से लेकर 1.0 था। 14 प्रजातियों के प्रति रोग निवारक आस्था (Fidelity Level - FL) का स्तर 100: पाया गया। और Eupatorium adenophorum प्रजाति के प्रति रोग निवारक आस्था का स्तर सबसे कम $(20 \%)$ पाया गया। सांस्कृतिक महत्व का सूचकांक 
(Cultural Importance Index) बद्ध सबसे अधिक (0.15), Barleria cristala प्रजाति के लिए पाया गया। जबकि सबसे कम स्तर (0.01) Azadirachta indica और Boehmeria rugulosa के लिए अंकित किया गया है।

निष्कर्षः अध्ययन से पता चला कि क्षेत्र में बड़ी संख्या में औषधीय पौधों की प्रजातियों मौजूद हैं। सतत विकास के माध्यम से इन औषधीय पौधों के प्रति संरक्षण के लिए जागरूकता बढ़ाना

एवं विकासात्मक रणनीति आवष्यक है।

कीवर्ड: ग्रामीणए आधारित पारम्परिक औषधीय पादप, ईलाज, बिमारी।

\section{Background}

Plants are an integral part of human society and are fulfilling many primary needs (e.g. food and shelter), and serve as cure for many diseases (WHO 2002; Jima and Megersa, 2018). India is one of the leading countries in Asia in the use of plants and harbors diverse traditional knowledge systems (Kala, 2005). Traditional medicine has been used by practitioners for thousands of years as primary human health care at community level and maintained its popularity worldwide (WHO, 2008). The practice of traditional medicine is widespread in China, India, Japan, Pakistan, Sri Lanka, Thailand, and Korea (Park et al. 2012), where several plants are used for the purposes.

The use of medicinal plants to treat various diseases has been a part of human culture since ancient times (van der Merwe et al. 2001). Historically, medicinal plants played a major role in the human societies (Lewis \& Lewis 2003). According to the World Health Organization (WHO), the use of traditional herbal medicine is widely practiced in both developing and industrialized countries as a complementary way to treat and to prevent illnesses (WHO 2003) and according the $\mathrm{WHO}$ estimates that $70-95 \%$ of the populations of developing countries rely mainly on medicinal plants for primary healthcare (WHO 2011), and in many cases their sale accounts for $15-30 \%$ of the total income of poorer households (Hamilton 2004). Traditionally medicinal plants have gained an important position in rural communities, particularly where Western style health care facilities are still not available.

The use of medicinal plants plays a significant role in the subsistence economy of local populations, especially those living in the mid-altitudes and the highlands (Sati 2013). About $65 \%$ of the Indian population depends on the traditional systems of medicine (Timmermans 2003). In addition to their daily use, some medicinal plants might have a potential for the development of allopathic drugs (Flaster 1996; Teklehaymanot\&Giday 2007).

The conservation of such plant genetic resources (PGR) is highly needed (Prakash 2011) to maintain the resources for future demand. The Indian Himalayan Region covers only about $18 \%$ of the Indian subcontinent, but harbours about 8000 angiosperms, 44 gymnosperms and 600 pteridophytes species (Singh \& Hajara 1996), of which 1748 species are used medicinally (Kala 2005;
Samant et al. 1998). Presently, the pharmaceutical industry of India is using 280 medicinal plant species, of which 175 are found in the Himalayan region (Dhar et al. 2000). In the rural areas of Garhwal Himalaya, the dependency of people on forests for ethnomedicine is increasing, especially with climate change allowing disease vectors to reach higher altitudes. However, the available resources are decreasing due to land use change and overharvesting. Keeping the dependency of local populations on forest resources in view, the hypotheses developed in the present study were (i) Villagers depend to a large extent on forest resources for fulfilling their daily livelihood needs. (ii) Plant selection for treating particular diseases is highly selective. (iii) Participants will have a high consensus, fidelity level and cultural importance level for the use of ethnomedicinal plants. With these hypotheses, our research focused on (i) documentation of ethnomedicinal plants used by the local population (ii) assessment of informant consensus, fidelity level and cultural importance of ethnomedicinal plants.

\section{Materials and Methods \\ Study site}

The present study was conducted in nine villages (Manjakot, Bhaisawada, Ghargaon, Pathawara, Sendri, Naugad, Chachakinda, Goni and Ulana) situated in close vicinity of forest fringes in Tehri district of Garhwal Himalaya (Table 1). The altitudinal range of the study villages ranged between 835 to $1547 \mathrm{~m}$ above sea level (Fig. 1). The mean recorded maximum temperature was $32^{\circ} \mathrm{C}$ (in June), and mean minimum temperature $4^{\circ} \mathrm{C}$ (in December). The mean relative humidity varies from $35 \%$ to $92 \%$ from May to August, respectively. The mean monthly rainfall ranges from $129 \mathrm{~mm}$ in July to $600 \mathrm{~mm}$ in August, and the average annual rainfall has been recorded as $1630 \mathrm{~mm}$. Tehri Garhwal is one of the western most districts of the Uttarakhand state. It is located at $30^{\circ} 3^{\prime} 00^{\prime \prime}$ to $30^{\circ} 53^{\prime} 00^{\prime \prime} \mathrm{N}$ latitude and $77^{\circ} 56^{\prime} 00^{\prime \prime}$ to $79^{\circ} 04^{\prime} 00^{\prime \prime} \mathrm{E}$ longitude on the outer ranges of the Central Himalaya, which includes low lying peaks rising contiguously from the plains of the northern India. The majority of the population depends on subsistence agriculture and animal husbandry. In addition the villagers use nearby forests for fuel, fodder, fibres, medicine and other daily needs. The dominant forest forming species close to study area are Anogeissus latifolia, Lannea coromendelica, Acacia catechu (tree layer) and Carrisa spinarum and Woodfordia fruticose (shrub layer) in the lower altitude of the study area. However; at higher altitude, the dominant species is Quercus leucotricophora with some common associated species (tree layer) and Berberis sp., Prenspia utilis, Rubus ellipticus (shrub layer). Pinus roxburghii is reported in the tree layer from lower to higher altitudes and providing basic needs to villagers. The literacy rate of the district is above $70 \%$.

\section{Fieldwork and data collection}


The fieldwork was carried out from January to October 2016. Information on ethnomedicinal plants uses was collected from those participants living close to the forest, which was done after establishing oral prior informed consent from the villagers. Of the total population, randomly selected inhabitants were chosen for semi structured interviews about their dependence on ethnomedicinal plants. Informants of all age groups and both genders were randomly selected (Table 1). The data about ethnomedicinal plants was collected from 93 respondents including 61 men and 32 women. All participants provided prior informed consent before the interviews. The participants were of $30-85$ years of age. The interviews were conducted in both Hindi and local dialect (Garhwali) using semi-structured questionnaires to obtain information on ethnomedicinal plant use, including detailed information on local names of plants, applications for a particular disease, plant parts used. To verify scientific names, the participants were asked to show the plants in their natural habitat. Specimens of all plants were collected and identified from Garhwal University Herbarium (GUH).

\section{Cultural dimensions of documented ethnomedicinal plants}

\section{Informant consensus factor}

The Informant Consensus was calculated on the basis of people's response on the plants number used for a particular purpose or ailment. The consensus factor $\left(F_{i c}\right)$ tests the homogeneity of the respondent's knowledge (Ragupathy et al. 2008; Trotter \& Logan 1986) and was calculated as follows:

$$
F_{\text {ic }}=\frac{N_{u r}-N_{t}}{N_{u r}-1}
$$

Where $\mathrm{N}_{\mathrm{ur}}=$ number of use-reports of respondents for a particular illness

$\mathrm{N}_{\mathrm{t}}=$ number of taxa used for a particular illness category by all respondents. The resulting range values between 0 to 1 . Here high value indicates for a high rate informant consensus.

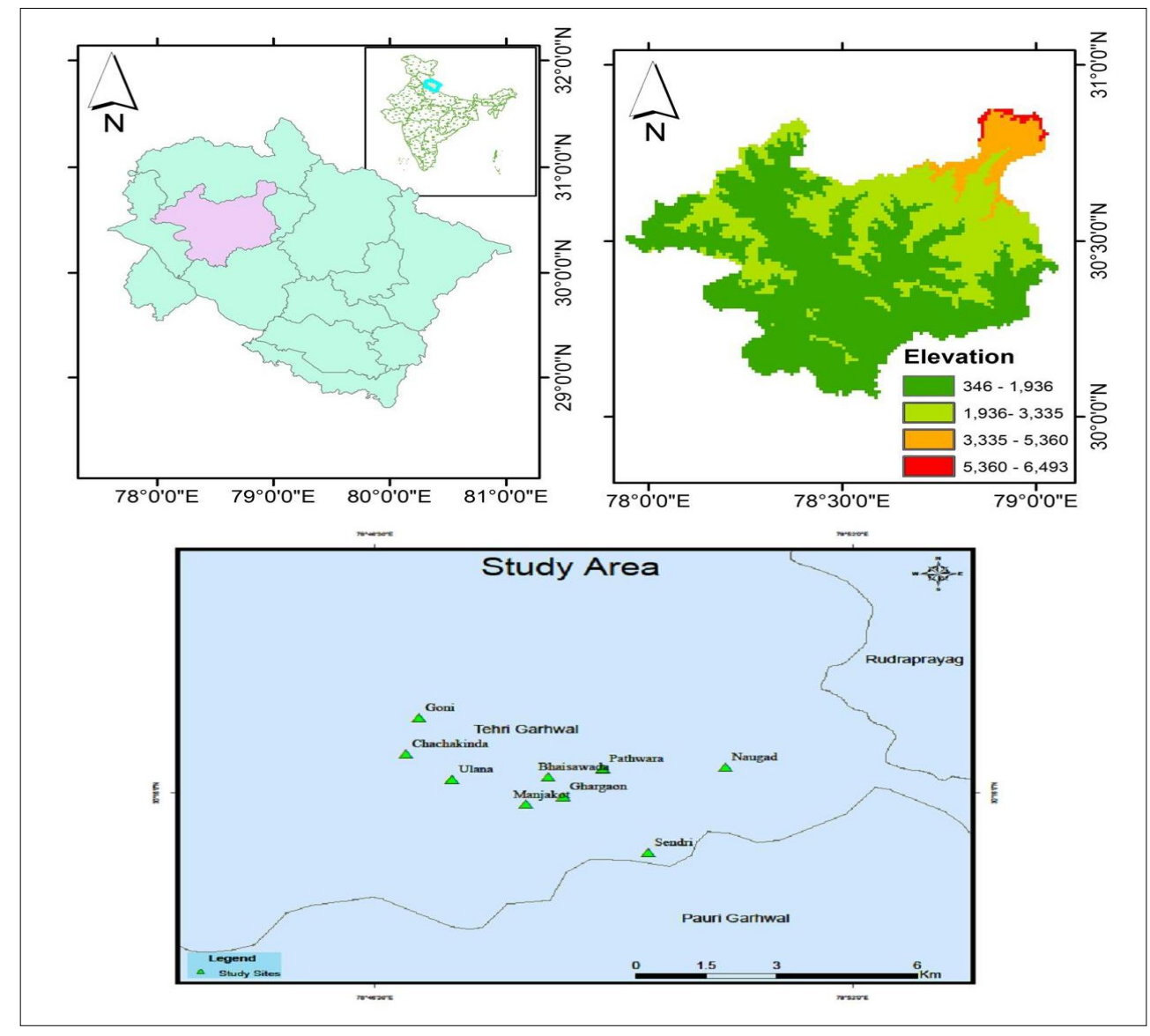

Figure 1. Location of study area 
Table 1. Details of the study villages

\begin{tabular}{|c|c|c|c|}
\hline Village & Latitude & Longitude & Elevation (m) \\
\hline Manjakot & $30^{\circ} 15^{\prime} 47.60^{\prime \prime} \mathrm{N}$ & $78^{\circ} 48^{\prime} 14.33^{\prime \prime E}$ & 835 \\
\hline Bhaisawada & $30^{\circ} 16^{\prime} 15.52^{\prime \prime} \mathrm{N}$ & $78^{\circ} 48^{\prime} 29.75^{\prime \prime} \mathrm{E}$ & 969 \\
\hline Ghargaon & $30^{\circ} 15^{\prime} 55.45^{\prime \prime} \mathrm{N}$ & $78^{\circ} 48^{\prime} 40.24^{\prime \prime E}$ & 1069 \\
\hline Pathwara & $30^{\circ} 16^{\prime} 24.57 " \mathrm{~N}$ & $78^{\circ} 49^{\prime} 07.57^{\prime \prime E}$ & 1421 \\
\hline Sendri & $30^{\circ} 14^{\prime} 58.27^{\prime \prime} \mathrm{N}$ & $78^{\circ} 49^{\prime} 39.12^{\prime \prime E}$ & 947 \\
\hline Naugad & $30^{\circ} 16^{\prime} 25.54^{\prime \prime} \mathrm{N}$ & $78^{\circ} 50^{\prime} 32.23 " \mathrm{E}$ & 1144 \\
\hline Chachakinda & $30^{\circ} 16^{\prime} 39.08^{\prime \prime} \mathrm{N}$ & $78^{\circ} 46^{\prime} 51.46^{\prime \prime} \mathrm{E}$ & 1547 \\
\hline Goni & $30^{\circ} 17^{\prime} 16.72 \mathrm{~N}$ & $78^{\circ} 47^{\prime} 00.56^{\prime \prime E}$ & 1169 \\
\hline Ulana & $30^{\circ} 16^{\prime} 13.75^{\prime \prime N}$ & $78^{\circ} 47^{\prime} 23.44^{\prime E}$ & 1427 \\
\hline
\end{tabular}

Fidelity level (FL)

The Fidelity level (FL) was calculated to elucidate the importance of a species in each group (Friedman et al. 1986; Pandikumar et al. 2010) as follows:

$$
\text { Fidelity level }(\mathrm{FL} \%)=\left(\frac{\mathrm{N}_{\mathrm{p}}}{\mathrm{N}}\right) \times 100
$$

$\mathrm{N}_{\mathrm{p}}$ is the number of informants citing the use of plants for a particular use category and $N$ is the total number of informants citing the species of any use category Increasing value of $F L$ for a species indicates its uniqueness to use a particular purpose.

\section{Cultural Importance Index (CI)}

The Cultural Importance Index $(\mathrm{Cl})$ is used to assess the importance of each species (Cls). It is calculated by dividing the number of use reports of the species by the number of informants (Aceituno-Mata 2010; Pardo-de-Santayana et al. 2007; Tardío\& Pardo-deSantayana 2008).

$$
\mathrm{CI}_{\mathrm{s}}=\sum_{\mathrm{u}=\mathrm{u}_{1}}^{\mathrm{u}_{\mathrm{NC}}} \sum_{\mathrm{i} \mathrm{i}_{1}}^{\mathrm{i}_{\mathrm{N}}} \mathrm{UR}_{\mathrm{ui}} /_{\mathrm{N}}
$$

Where, UR =number of use reports of species for different use category (NC) and $\mathrm{N}=$ number of total informants.

\section{Results and discussion}

Floristic composition

In the present study, a total of 92 plant species belonging to 82 genera and 49 families were reported. These life forms were dominated by trees (52) followed by shrubs (19), herbs (18) and climbers (3). Out of the 92 reported species, only 35 plant species belonging to 25 families were used for medicinal purposes. The dominant families were Combretaceae and Euphorbiaceae with three plant species each followed by Anacardiaceae, Lamiaceae, Moraceae, Rutaceae, Urticaceae and Verbenaceae (2) each. In each village people used preferentially trees, followed by shrubs, herbs and climbers, except in the village Chachkinda, where the highest numbers of useful species were herbs, followed by trees and shrubs. The maximum number of species (44) was reported in Bhainswara followed by Manjakot (36 species), Sendri (34 species), Ulana (25 species), Pathawara and Goni (23 species each), Chachakinda (15 species), Ghargaon (7 species), and a minimum in Naugad (3 species). The highest number of species used for medicinal purposes was found in Bhainswara, where most species served medicinal values purposes.

\section{Consensus survey of medicinal plants}

In the present study the consensus factor for joint pain was 0.00 followed by healing wounds $(0.600)$, stomach problems (including indigestion and stomach ache) (0.600), fractures (0.714), constipation (0.750), diabetes (0.824), tooth problems includes cleaning, tooth ache and swelling of gum (0.846), dysentery (0.875), cough (0.889) and 1.0 for arthritis, eye irritation, kidney stone, blister of the mouth, piles, killing insects (parasites of animals), garget (mastitis), removing spines, heart problems, thirst, typhoid fever, anaemia, headache, jaundice, blood clothing, cuts, spider bite blisters, acidity, glowing face, boils, and neck pain. The consensus survey indicated that twenty one plant species with informant's consensus index factor of (1.0) were used most commonly for individual diseases. Two taxa were often used for cough and dysentery, with consensus factors values of 0.889 and 0.875 , respectively. Three taxa were used for tooth problems (cleaning, tooth ache and swelling of gum), fractures and healing wounds, with consensus factors of $0.846,0.714$ and 0.600 . Four taxa were used for diabetes (0.906) and constipation (0.750). Stomach problems (indigestion and stomach ache) were cured with the highest number of taxa (5) having a consensus factor of 0.600 (Table 2). The respondents had a high level of agreement on plants use for specific ailments. Uddin and Hassan (2014) reported values of $F_{\text {ic }}$ from 0.50 to 0.95 with an average value of 0.73 , with highest $(0.95) F_{\text {ic }}$ value for dysentery. The highest consensus species was Litsea glutinosa. The very high $\mathrm{F}_{\mathrm{IC}}$ value for dysentery indicates that this ailment is common in the study area due to poor sanitation and there is wide communication established among informants for treating this ailment.

A study by Bhat et al. (2013) in Kedarnath Wildlife Sanctuary from Garhwal Himalaya found higher $F_{\text {ic }}$ for Haematological illnesses (1.00), followed by 
dermatological and ophthalmological illnesses (0.98). The $F_{\text {ic }}$ for urological problems and general surgery in their study was (0.97) while for gastroenterological problems and general medicine categories $F_{\text {ic }}$ was 0.92 and 0.85 respectively. Kumar et al. (2011) conducted a study in the lower belts of the Himalayas and also found high levels of agreement regarding the usages of single plants with $F_{i c}$ value in the range of 0.33 to 1.0 . The $F_{i c}$ was highest for warts, vomiting, carminative, pain, boils and antiseptic uses (1.0), and lowest for bronchitis (0.33). Namsa et al. (2011) documented 50 plants species belonging to 29 families used for treating 22 human and 4 veterinary ailments among the Monpa ethnic community of Arunachal Pradesh. The consensus analysis revealed that dermatological ailments had the highest $F_{\text {ic }}(0.56)$, while the $F_{\text {ic }}$ for gastro-intestinal diseases was 0.43. However, general health and miscellaneous diseased had values of 0.20 and 0.17 respectively. High informant consensus (0.875) was also recorded by Owuor and Kisangau (2006) among the snakebite healers in Kamba of Africa and treating 'mich' or febrile diseases (0.80) among North-western Ethiopia (Teklehaymanot \&nGiday 2007). Uddin and Hassan (2014) suggested that the plant species have high informant consensus factor, use report and fidelity level should be given priority to carry out studies on efficacy and toxicity.

Table 2. Informant consensus for ethnomedicinal plants

\begin{tabular}{|c|c|c|c|}
\hline Illness category & $\begin{array}{c}\text { Number of taxa } \\
\text { used }\left(\mathrm{N}_{\mathrm{t}}\right)\end{array}$ & $\begin{array}{c}\text { Number of } \\
\text { use-reports }\left(\mathrm{N}_{\mathrm{ur}}\right)\end{array}$ & $\begin{array}{l}\text { Informant consensus } \\
\text { index factor }\left(\mathrm{F}_{\mathrm{ic}}\right)^{*}\end{array}$ \\
\hline Acidity & 1 & 2 & 1.000 \\
\hline Anaemia & 1 & 3 & 1.000 \\
\hline Arthritis & 1 & 5 & 1.000 \\
\hline Blister of mouth & 1 & 3 & 1.000 \\
\hline Blood clotting & 1 & 2 & 1.000 \\
\hline Boils & 1 & 2 & 1.000 \\
\hline Constipation & 4 & 13 & 0.750 \\
\hline Cough & 2 & 10 & 0.889 \\
\hline Cuts & 1 & 2 & 1.000 \\
\hline Diabetes & 4 & 18 & 0.824 \\
\hline Dysentery & 2 & 9 & 0.875 \\
\hline Eye irritation & 1 & 3 & 1.000 \\
\hline Fractures & 3 & 8 & 0.714 \\
\hline Garget(mastitis) & 1 & 2 & 1.000 \\
\hline Glowing face & 1 & 6 & 1.000 \\
\hline Headache & 1 & 2 & 1.000 \\
\hline Healing wounds & 3 & 6 & 0.600 \\
\hline Heart problems & 1 & 3 & 1.000 \\
\hline Jaundice & 1 & 3 & 1.000 \\
\hline Joint pain & 1 & 1 & 0.000 \\
\hline Kidney stone & 1 & 3 & 1.000 \\
\hline $\begin{array}{l}\text { Killing insects } \\
\text { (parasites of animals) }\end{array}$ & 1 & 2 & 1.000 \\
\hline Neck pain & 1 & 2 & 1.000 \\
\hline Piles & 1 & 2 & 1.000 \\
\hline Remove spines & 1 & 3 & 1.000 \\
\hline Spider bite blister & 1 & 4 & 1.000 \\
\hline Stomach problems & & & \\
\hline $\begin{array}{l}\text { (indigestion and stomach } \\
\text { ache) }\end{array}$ & 5 & 11 & 0.600 \\
\hline Thirst & 1 & 4 & 1.000 \\
\hline $\begin{array}{l}\text { Tooth problems (cleaning, } \\
\text { tooth ache and swelling of } \\
\text { gum) }\end{array}$ & 3 & 14 & 0.846 \\
\hline Typhoid fever & 1 & 3 & 1.000 \\
\hline
\end{tabular}

${ }^{*} \mathrm{~F}_{\mathrm{ic}}=\mathrm{N}_{\mathrm{ur}}-\mathrm{N}_{\mathrm{t}} /\left(\mathrm{N}_{\mathrm{ur}}-1\right)$, providing a value between 0 and 1 , where high value indicates a high rate of informants consensus.

Fidelity Level (FL \%)

The Fidelity Level (FL) of plants is given in Table 3. In the present study the species with the highest FL $(100 \%)$ were Terminalia bellirica, Terminalia chebula, Mangifera indica, Juglans regia,
Zanthoxylum armatum, Syzygium cumini, Quercus leucotrichophora, Boehmeria rugulosa, Euphorbia royleana, Litseag lutinosa, Aegle marmelos, Ajuga parviflora, Azadirachta indica and Rumex dentatus, which were used for cough, dysentery, tooth ache, 
diabetes, constipation, fractures, stomach problem and healing wounds. The lowest FL was found for Eupatorium adenophorum (20\%) used for wound healing. High (100\%) FL was also reported from other studies, e.g. for Azadirachta indica (Muthuet al. 2006).
Cultural Importance Index (CI)

The Cultural Importance Index $(\mathrm{Cl})$ was highest for Barleria cristata (0.15) followed by Rhus parviflora (0.11) and Carissa carandas(0.10). Lowest values of this index were observed for Azadirachta indica (0.01) and Boehmeria rugulosa (0.01) (Table 4).

Table 3. Fidelity level of observed species of study area

\begin{tabular}{|l|l|}
\hline $\begin{array}{l}\text { Illness } \\
\text { category* }\end{array}$ & \multicolumn{1}{c|}{ Fidelity level of species (\%) } \\
\hline Cough & Terminalia bellirica(100.00), Terminalia chebula(100.00), \\
\hline Dysentery & Mangifera indica(100.00), Rhu sparviflora (30.00) \\
\hline $\begin{array}{l}\text { Tooth } \\
\text { problems }\end{array}$ & Juglan sregia (100.00), Rhus parviflora (30.00), Zanthoxylum armatum (100.00) \\
\hline Diabetes & $\begin{array}{l}\text { Berberis asiatica (57.14), Carissa carandas (33.33), } \\
\text { Syzygium cumii (100.00), Tinospora cordifolia (50.00) }\end{array}$ \\
\hline Constipation & $\begin{array}{l}\text { Emblica officinale (28.57), Flacourtia indica (37.50), } \\
\text { Premna barbata (50.00), Quercus leucotrichophora (100.00) }\end{array}$ \\
\hline Fractures & $\begin{array}{l}\text { Boehmeria rugulosa (100.00), Euphorbia royleana (100.00), } \\
\text { Litseag lutinosa (100.00) }\end{array}$ \\
\hline $\begin{array}{l}\text { Stomach } \\
\text { problems }\end{array}$ & $\begin{array}{l}\text { Aegle marmelos (100.00), Ajuga parviflora (100.00), } \\
\text { Anogeissus latifolia (66.67), Azadirachta indicia (100.00), } \\
\text { Rumex dentatus (100.00) }\end{array}$ \\
\hline $\begin{array}{l}\text { Healing } \\
\text { wounds }\end{array}$ & $\begin{array}{l}\text { Agave americana (33.33), Carissa carandas (44.44), } \\
\text { Eupatorium adenophorum (20.00), }\end{array}$ \\
\hline
\end{tabular}

*Only categories with more than one observed plant species

Ethnomedicinal uses of plant

Out of 35 plant species for which ethnomedicinal uses were reported, 5 were used for stomach problems (digestion and stomach ache), 4 for diabetes, 3 species each for healing wounds, constipation and fractures, 2 species each for cough and dysentery, and 1 species each for arthritis, joint pain, eye irritations, tooth problems (cleaning, tooth ache and swelling of gum), kidney stone, blisters of the mouth, piles, killing insect parasites in animals, garget (mastitis) of women and animals, remove spines in humans, heart problems, thirst, typhoid fever, anaemia, headache, jaundice, blood clotting, cuts, spider bite blisters, glowing face (cosmetic), acidity, boils and neck pain. Of these 35 species, 19 species were reported for the first time from this region (Agave americana, Ajuga parviflora, Anogeissus latifolia, Azadirachta indica, Callicarpa macrophylla, Carissa carandus, Colebrookea oppositifolia, Dalbergia sissoo, Euphorbia royleana, Ficus palmata, Ficus roxburghii, Flacourtia indica, Mallotus philippensis, Mangifera indica, Nyctanthes arbor-tristis, Premna barbata, Rumex dentatus, Solanum incanum, Viola canescens (Table 4). The uses of other sixteen species have also been reported by other authors (Table 4) (Bhat et al. 2013; Gaur \& Sharma 2011; Malik et al. 2015; Semwal et al. 2010; Uniyal \& Shiva 2005).

\section{Conclusions}

Our research confirmed the hypotheses that the local population depends to a large extent on forest resources for their daily livelihood needs. The results also confirmed that the use of the plants for treating a particular disease was highly selective. Informants had a very high consensus, fidelity level and cultural importance level for the use of ethnomedicinal plants. However; these valuable species are under pressure due to their use as fuelwood, fodder, timber therefore, there is an urgent need to formulate suitable conservation strategies for local villagers for naturally growing ethnomedicinal plants for continuous and sustainable use in the future. 
Table 4. Documentation of ethnomedicinal plant species in the study area with some earlier reporting

\begin{tabular}{|c|c|c|c|c|c|}
\hline $\begin{array}{l}\text { Scientific name / } \\
\text { Voucher number }\end{array}$ & Family & Local Name & Ailments & $\begin{array}{l}\mathrm{Cl} \\
\text { value }\end{array}$ & Early reports from Garhwal Himalaya \\
\hline Barleria cristata L. & Acanthaceae & Marchunda & Spider bite blister & 0.043 & Uniyal and Shiva, 2005 \\
\hline $\begin{array}{l}\text { Mangifera indica L. } \\
\text { GUH-21006 }\end{array}$ & Anacardiaceae & Aam & Dysentery & 0.065 & r \\
\hline $\begin{array}{l}\text { Rhus parviflora Roxb } \\
\text { GUH-21007 }\end{array}$ & Anacardiaceae & Tung & Thirst, dysentery, cleaning teeth & 0.108 & Semwalet al., 2010 \\
\hline $\begin{array}{l}\text { Carissa carandas L. } \\
\text { GUH-21011 }\end{array}$ & Apocynaceae & Karaunda & $\begin{array}{l}\text { Wounds, killing insects(parasites of } \\
\text { animals), diabetes }\end{array}$ & 0.097 & - \\
\hline Agave americana $\mathrm{L}$. & Asparagaceae & Patavaar & Boils, wounds & 0.032 & - \\
\hline $\begin{array}{l}\text { Eupatorium adenophorum Spreng. } \\
\text { WR-BSD-118412 }\end{array}$ & Asteraceae & $\begin{array}{l}\text { Kala } \\
\text { baansa }\end{array}$ & Blood drawing, cssut, wound & 0.054 & $\begin{array}{l}\text { Uniyal and Shiva, 2005; Gaur and } \\
\text { Sharma, 2011; Semwalet al., 2010; } \\
\text { Bhatet al., 2013; Malik et al., 2015 }\end{array}$ \\
\hline $\begin{array}{l}\text { Berberis asiatica Roxb. ex DC. GUH- } \\
21018\end{array}$ & Berberidaceae & Kingod & Diabetes, eye irritation, kidney stones & 0.151 & $\begin{array}{l}\text { Pala et al., 2010; Kala, 2007; Malik et } \\
\text { al., 2015; Singh et al., } 2014\end{array}$ \\
\hline $\begin{array}{l}\text { Anogeissus latifolia (Roxb. ex. DC.) Wall. } \\
\text { ex Bedd. }\end{array}$ & Combretaceae & Dhauda & Stomach problems, joint pain & 0.032 & r \\
\hline $\begin{array}{l}\text { Terminalia bellirica (Gaertn.) Roxb GUH- } \\
21024\end{array}$ & Combretaceae & Baheda & Cough & 0.043 & Uniyal and Shiva, 2005 \\
\hline Terminalia chebula Retz. GUH-21025 & Combretaceae & Heda & Cough & 0.065 & Kala, 2007; Uniyal and Shiva, 2005 \\
\hline Euphorbia royleana Boissier & Euphorbiaceae & Sullu & Fractures & 0.043 & - \\
\hline Mallotus philippensis (Lam.) Müll.-Arg. & Euphorbiaceae & Ruina & Neck pain & 0.022 & - \\
\hline $\begin{array}{l}\text { Dalbergia sissoo Robx. ex DC. WR-BSD- } \\
118424\end{array}$ & Fabaceae & Shisham & Garget (mastitis in women and animals) & 0.022 & $\mathrm{CH}$ \\
\hline $\begin{array}{l}\text { Quercus leucotrichophora A.Camus } \\
\text { GUH-21041 }\end{array}$ & Fagaceae & Banj & Constipation & 0.022 & $\begin{array}{l}\text { Pala et al., 2010; Kumar at al., 2011; } \\
\text { Uniyal and Shiva, 2005; Gaur and } \\
\text { Sharma, 2011; Singh et al., } 2014\end{array}$ \\
\hline Flacourtia indica (Burm. f.) Merrill & Flacourtiaceae & Bilangara & Constipation & 0.032 & - \\
\hline $\begin{array}{l}\text { Juglans regia L. } \\
\text { GUH-21042 }\end{array}$ & Juglandaceae & Akharot & Cleaning teeth, tooth ache & 0.054 & $\begin{array}{l}\text { Kala, 2007; Kumar et al., 2009; } \\
\text { Uniyal and Shiva, 2005; Singh and } \\
\text { Rawat, 2011; Semwalet al., 2010; } \\
\text { Bhatet al., 2013; Malik et al., } 2015\end{array}$ \\
\hline Ajuga parviflora Benth. & Lamiaceae & Neelkanth & Stomach pain & 0.022 & - \\
\hline Callicarpa macrophylla Vahl & Lamiaceae & Daiya & Blister of the mouth & 0.032 & - \\
\hline Colebrookea oppositifolia Sm. & Lamiaceae & Binda & Piles & 0.022 & - \\
\hline Premna barbata Wallich ex Schauer & Lamiaceae & Bakare & Acidity, constipation & 0.043 & - \\
\hline Litsea glutinosa (Lour.) C.B. Rob. & Lauraceae & $\begin{array}{l}\text { Maida } \\
\text { akadi }\end{array}$ & Bone fractures & 0.032 & Malik et al., 2015 \\
\hline
\end{tabular}

Published: 02 May 2019

http://dx.doi.org/10.32859/era.18.14.1-11 
Ethnobotany Research and Applications

\begin{tabular}{|c|c|c|c|c|c|}
\hline Azadirachta indica A. Juss. & Meliaceae & Neem & Stomach pain & 0.011 & - \\
\hline $\begin{array}{l}\text { Tinospora cordifolia( Willd.) Miers ex } \\
\text { Hook.f. \&Thomson GUH-21055 }\end{array}$ & Menispermaceae & Giloya & Diabetes, typhoid fever & 0.065 & $\begin{array}{l}\text { Uniyal and Shiva, 2005; Negiet al., } \\
\text { 2002; Gaur and Sharma, } 2011\end{array}$ \\
\hline Ficus palmata Forssk. & Moraceae & Bedu & Remove spines & 0.032 & - \\
\hline Ficus roxburghii Steud. & Moraceae & Timala & Heart related & 0.032 & - \\
\hline Syzygium cumini( L.) SkeelsGUH-21063 & Myrtaceae & Jaamun & Diabetes & 0.043 & Malik et al., 2015 \\
\hline Nyctanthes arbor-tristis L. & Oleaceae & Harsingar & Arthritis & 0.054 & - \\
\hline Phyllanthus emblica Gaertn. GUH-21033 & Phyllanthaceae & Amala & Constipation & 0.065 & Uniyal and Shiva, 2005 \\
\hline $\begin{array}{l}\text { Rumex dentatus L. } \\
\text { GUH-21072 }\end{array}$ & Polygonaceae & Emada & Stomach pain & 0.032 & 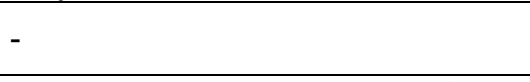 \\
\hline Aegle marmelos(L.) CorrêaGUH-21081 & Rutaceae & Bel & Stomach problems & 0.032 & $\begin{array}{l}\text { Kumar at al., 2011; Uniyal and Shiva, } \\
2005\end{array}$ \\
\hline Zanthoxylu marmatum DC. GUH-21084 & Rutaceae & Temaru & Cleaning teeth, swelling of gum & 0.065 & $\begin{array}{l}\text { Phondaniet al., 2010; Kala, 2007; } \\
\text { Uniyal and Shiva, 2005; Singh and } \\
\text { Rawat, 2011; Semwalet al., 2010; } \\
\text { Bhatet al., 2013; Malik et al., } 2015\end{array}$ \\
\hline Solanum incanum L. & Solanaceae & Bukandari & Jaundice & 0.032 & - \\
\hline Boehmeria rugulosa Wedd & Urticaceae & Genthi & Bone fractures (veterinary) & 0.011 & Malik et al., 2015 \\
\hline $\begin{array}{l}\text { Urtica dioica L. } \\
\text { GUH-81087 }\end{array}$ & Urticaceae & Kandaali & Anaemia, headache & 0.054 & Phondaniet al., 2010 \\
\hline Viola canescens Wallich & Violaceae & Sumaya & Glowing face & 0.065 & - \\
\hline
\end{tabular}


Declarations:

List of abbreviations: Not applicable

Ethics approval and consent to participate: All participants provided oral prior informed consent.

Consent for publication: Not applicable

Competing interest: Not applicable

Funding: Not applicable

Author contributions: APS and MK designed the study and developed this manuscript, BN, NAP, and RWB improved the manuscript, gave methodological input and revised the taxonomy.

Acknowledgments: The authors are thankful to all the participants for sharing their knowledge.

\author{
Author details: \\ Atul Pratap Singh ${ }^{1}$ \\ Munesh Kumar $^{1^{*}}$ \\ Bhuvnesh Nagar ${ }^{2}$ \\ Nazir A. Pala ${ }^{3}$ \\ Rainer W. Bussmann ${ }^{4}$
}

${ }^{1}$ Department of Forestry and Natural Resources, HNB Garhwal University (A Central University), Srinagar Garhwal, Uttarakhand 249161, India

2Department of Forest Products and Utilization, College of Horticulture and Forestry, Jhalawar, Rajasthan 326023, India

${ }^{3}$ Faculty of Forestry, SKUAST, Kashmir, Benhama Watlar Ganderbal (J \& K)

${ }^{4}$ llia State University, Institute of Botany and Bakuriani Alpine Botanical Garden, Department of Ethnobotany, 1 Botanical Str. 0105 Tbilisi Georgia, Georgia;

\section{*corresponding author: muneshmzu@yahoo.com}

\section{Literature Cited}

Aceituno-Mata L. 2010. Estudioetnobotánico y agroecológico de la Sierra Norte de Madrid. Ph.D. Thesis. Universidad Autónoma de Madrid, Spain.

Bhat JA, Kumar M, Bussmann RW. 2013. Ecological status and traditional knowledge of medicinal plants in Kedarnath Wildlife Sanctuary of Garhwal Himalaya, India. Journal of Ethnobiology and Ethnomedicine 9(1). doi:10.1186/1746-4269-9-1.

Bhat JA, Kumar M, Negi AK, Todaria NP. 2013. Informants' consensus on ethnomedicinal plants in Kedarnath Wildlife Sanctuary of Indian Himalayas. Journal of Medicinal Plants Research 7(4):148-154.

Biodiversity status in the Himalaya. British council, New Delhi, India, pp. 19-38.

Dhar U, Rawal RS, Upreti J. 2000. Setting priorities for conservation of medicinal plants- A case study in
Indian Himalaya. Biological Conservation 95(1): 5765.

Flaster T. 1996. Ethnobotanical approach to drug discovery of bioactive compounds. Process in new crops. Proceedings of the Third Traditional Symposium, ASHS press, Alexandria, USA, pp. 561565.

Friedman J, Yaniv Z, Dafni A, Palewitch D.1986. A preliminary classification of the healing potential of medicinal plants, based on rational analysis of an ethnopharmacological field survey among Bedouins in Negev desert, Israel. Journal of Ethnopharmacology 16:275-287.

Gaur RD, Sharma J. 2011. Indigenous Knowledge on the Utilization of Medicinal Plant Diversity in the Siwalik Region of Garhwal Himalaya, Uttarakhand. Journal of Forest Science27(1):23-31.

Jima TT, Megersa M, 2018.Ethnobotanical Study of Medicinal Plants Used to Treat Human Diseases in Berbere District, Bale Zone of Oromia Regional State, South East Ethiopia. Evidence-Based Complementary and Alternative Medicine18: 1-17.

Kala CP. 2005. Current status of medicinal plants used by traditional Vaidhyas in Uttaranchal State of India. Ethnobotany Research and Application 3:267278.

Kala CP. 2007. Local preferences of ethnobotanical species in the Indian Himalaya: Implications for environmental conservation. Current Science 93:1225.

Kumar M, Sheikh MA, Bussmann RW. 2011. Ethnomedicinal and ecological status of plants in Garhwal Himalaya, India. Journal of Ethnobiology and Ethnomedicine 7:32.

Kumar P, Gupta S, Singh SB. 2009. Ethnobotanical Studies of Nubra Valley - A Cold Arid Zone of Himalaya. Ethnobotanical Leaflets 13:752-765.

Kumar S, Kumar R, Khan A. 2011. Medicinal plant resources: manifestation and prospects of lifesustaining healthcare system. Continental Journal of Biological Science 4(1):19-29.

Lewis WH, Elwin Lewis MP. 2003. Medical botany Plants affecting human health. John Wiley and sons, New York, USA.

Malik ZA, Bhat JA, Ballabha R, Bussmann RW, Bhatt AB. 2015. Ethnomedicinal plants traditionally used in health care practices by inhabitants of Western Himalaya. Journal of Ethnopharmacology 172:133144.

Muthu C, Ayyanar M, Raja N, Ignacimuthu S. 2006. Medicinal plants used by traditional healers in Kancheepuram District of Tamil Nadu, India. Journal of Ethnobiology and Ethnomedicine2:43. 
Namsa ND, Mandal M, Tangjang S, Mandal SC. 2011. Ethnobotany of the Monpa ethnic group at Arunachal Pradesh, India. Journal of Ethnobiology and Ethnomedicine7:31.

Negi CS, Nautiyal S, Dasila L, Rao KS, Maikhuri RK. 2002. Ethnomedicinal Plant Uses in a Small Tribal Community in a Part of Central Himalaya, India Journal of Human Ecology 14(1):23-31.

Owuor BO, Kisangau DP. 2006. Kenyan medicinal plants used as antivenin: a comparison of plant usage. Journal of Ethnobiology and Ethnomedicine 2:(7).

Pala NA, Negi AK, Todaria NP. 2010. Traditional uses of medicinal plants of Pauri Garhwal, Uttrakhand. Nature and Science 8(6):57-61.

Pandikumar P, Chellappandian M, Mutheeswaran S, Ignacimuthu S. 2011. Consensus of local knowledge on medicinal plants among traditional healers in Mayiladumparai block of Theni District, Tamil Nadu, India. Journal of Ethnopharmacology 134:354-362.

Pardo-de-Santayana M, Tardío J, Blanco E, Carvalho AM, Lastra JJ, San Miguel E, Morales R. 2007. Traditional knowledge on wild edible plants in the northwest of the Iberian Peninsula (Spain and Portugal): a comparative study. Journal of Ethnobiology and Ethnomedicine 3:27.

Park HL, Lee HS, Shin BC, Shin BC, Liu JP, Shang Q, Yamashita H, Lim B. 2012. Traditional medicine in China, Korea, and Japan :a brief introduction and comparison. Evidence-Based Complementary and Alternative Medicine 1-9

Phondani PC, Maikhuri RK, Rawat LS, Farooquee NA, Kala CP, Vishvakarma SCR, Rao KS, Saxena KG. 2010. Ethnobotanical Uses of Plants among the Bhotiya Tribal Communities of Niti Valley in Central Himalaya, India. Ethnobotany Research and Application8:233-244.

Prakash A. 2011. Uses of some threatened and potential ethnomedicinal plants among the tribals of Uttar Pradesh and Uttrakhand in India, National Conference on Forest Biodiversity: Earth's Living Treasure. Uttar Pradesh State Biodiversity Board, Locknow, U.P., India.

Ragupathy S, Steven NG, Muruthakkutti M, Velusamy B. 2008. Consensus of the Malasars traditional aboriginal knowledge of medicinal plants in the velliangiri holy hills, India. Journal of Ethnobiology Ethnomedicine4:8doi:10.1186/1746-4269-4-8.

Samant SS, Dhar U, Palni LMS. 1998. Medicinal plants of Indian Himalaya; Diversity distribution potential value. GB Pant institute of Himalayan environment and development. Kosi Katarmal Almora, India.
Sati VP. 2013. Cultivation of medicinal plants and its contribution to livelihood enhancement in the Indian Central Himalayan Region. Advances in Medicinal Plant Research 1(2):17-23.

Semwal DP, Saradhi PP, Kala CP, Sajwan BS. 2010. Medicinal plants used by local VaidyasinUkhimath block, Uttarakhand. Indian Journal of Traditional Knowledge 9(3):480-485.

Singh DK, Hajara PK. 1996. Floristic diversity. In Gujral GS, Sharma V eds.

Singh G, Rawat GS. 2011.Ethnomedicinal survey of Kedarnath wildlife sanctuary in Western Himalaya, India. Indian Journal of Fundamental Applied Life Science 1:35-46.

Singh H, Husain T, Agnihotri P, Pande PC, Khatoon S. 2014. An ethnobotanical study of medicinal plants used in sacred groves of Kumaon Himalaya, Uttarakhand, India. Journal of Ethnopharmacology, 154(1): 98-108 doi:10.1016/j.jep.2014.03.026i.

Singh MP, Dey S. 2005.Indian Medicinal Plants. Satish Serial Publishing House, New Delhi, India.

Tardío J, Pardo de Santayana M. 2008. Cultural importance indices: a comparative analysis based on the useful wild plants of Southern Cantabria. Economic Botany 62 (1):24-39.

Teklehaymanot T, Giday M. 2007. Ethnobotanical study of medicinal plants used by people in Zegie Peninsula, Northwestern Ethiopia. Journal of Ethnobiology and Ethnomedicine 3:12.

Timmermans K. 2003. Intellectual Property Rights and Traditional Medicine: Policy Dilemmas at the Interface. World Health Organization, Jakarta, Indonesia.

Trotter R, Logon M. 1986. Informant consensus: a new approach for identifying potentially effective medicinal plants. In plants indigenous medicine and diet: biobehavioural approaches. Redgrave, New York, USA, pp. 91-112.

Uddin MZ, Hassan MA. 2014. Determination of informant consensus factor of ethnomedicinal plants used in Kalenga forest, Bangladesh. Bangladesh Journal of Plant Taxonomy21(1):83-91.

Uniyal B, Shiva V. 2005. Traditional knowledge on medicinal plants among rural women of Garhwal Himalaya Uttarakhand, Indian Journal of Traditional Knowledge 4(3):259-266.

van der Merwea D, Swana GE, Botha CJ. 2001. Use of ethnoveterinary medicinal plants in cattle by Setswana-speaking people in the Madikwe area of the North West Province of South Africa. Journal of South African Veterinary Association 72:189-196. 
WHO. 2001. World Health Organization traditional medicine strategy, 2002-2005. Geneva, Switzerland.

WHO. 2002. Traditional Medicine: Growing Needs and Potentials, Geneva, Switzerland.

WHO. 2003.Traditional Medicine. Fact sheet No. 134. Geneva, Switzerland.

WHO. 2011. The World Medicines Situation, Traditional Medicines: Global Situation, Issues and Challenges. Geneva, Switzerland. http://www.who.int/ medicines/areas/policy/world_medicines_situation/ WMS_ch18_wTraditionalMed.pdf.

WHO. 2012. Traditional medicine. http://www.who.int/ mediacentre/factsheets/fs34/en. 